\title{
A NEW PRACTICAL METHOD TO PREVENT HYPOCALCAEMIA IN DAIRY COWS AT PASTURE
}

\author{
Gavin F. Wilson
}

Institute of Veterinary, Animal and Biomedical Sciences, Massey University, Palmerston North, New Zealand. G.F.Wilson@massey.ac.nz

Introduction: As milk production levels from New Zealand cows increase so too does the incidence of parturient milk fever and other disorders associated with sub-clinical hypocalcaemia. Pastures typically contain $4-5 \mathrm{~g} \mathrm{Ca}$ (and $25-45 \mathrm{~g} \mathrm{~K}$ ) $/ \mathrm{kg} \mathrm{DM}$, high enough prepartum to down-regulate physiological mechanisms that can supply extra $\mathrm{Ca}$, yet too low in $\mathrm{Ca}$ to meet requirements of the milking cow. Supplementation of grazing cows with minerals is difficult, and it is particularly impractical to provide sufficient anionic salts to reach recommended DCAD values without experiencing palatability problems.

Recently, a means of specifically stimulating the capacity of ewes to absorb Ca from their diet during late pregnancy, thereby making them more resistant to fasting-induced hypocalcaemia, was discovered (Calcigard concept; Wilson, 2001). This nutritional strategy involved feeding a vegetable oil supplement, which formed poorly digestible Ca soaps in the GIT for a period of 3 weeks, and resulted in a marked activation of $\mathrm{Ca}$ homeostasis.

Aim: The objective of the current experiment was to examine the effects of a prototype feed supplement (Calcigard Concentrate, $\mathrm{CC}$ ), designed to reduce the availability of dietary calcium during late pregnancy, on the incidence of milk fever and other aspects of health and production in grazing dairy cows.

Methods: Mixed breed dairy cows ( $\mathrm{n}=176)$ in 4 commercial herds were fed CC (at $1 \mathrm{~kg} / \mathrm{day}$ ) for up to three weeks immediately prior to parturition. The incidences of health problems, and productivity in early lactation, were compared with data from a similar untreated control group $(n=224)$. Mineral concentrations in the pre- and post-calving feeds were also determined.

Results: The incidence of milk fever was markedly reduced (23 to 7\%), milksolids (fat + protein) production in early lactation increased (8\%), and other aspects of herd health (Somatic Cell Counts, calf losses, retained placenta) improved by CC feeding.

\begin{tabular}{lccccccc}
\hline & $\mathrm{N}$ & $\begin{array}{c}\text { Milk } \\
\text { fever } \%\end{array}$ & $\mathrm{P}$ & $\begin{array}{c}\text { Milksolids } \\
\mathrm{Kg} / \text { cow daily }\end{array}$ & $\mathrm{P}$ & $\begin{array}{c}\text { Somatic Cell } \\
\% \text { 100,000+ }\end{array}$ & $\mathrm{P}$ \\
\hline Control & 224 & 23 & - & 1.91 & - & 41 & - \\
Calcigard 2-3 wk & 176 & 7 & .01 & 2.06 & .01 & 32 & .05 \\
\hline
\end{tabular}

Differences in the incidence of milk fever between herds were associated with pasture potassium concentrations $(r=0.63)$ in early lactation, but not with DCAD values, pre-calving. Pasture calcium, magnesium and sodium concentrations were inversely related to pasture potassium concentrations.

Conclusion: The Calcigard strategy (and product) reported here clearly holds considerable promise to provide dairy farmers with a practical means to prevent parturient disorders associated with $\mathrm{Ca}$ deficiency, and improve animal welfare, health and production. Reference: Wilson GF (2001), New Zealand Veterinary Journal 49:115-8 